\title{
Effect of different flooring types on pressure distribution under the bovine claw - an ex vivo study
}

\author{
Benjamin Oehme ${ }^{1 *} \mathbb{D}$, S. M. Geiger ${ }^{1,2}$, S. Grund ${ }^{1}$, K. Hainke$^{1}$, J. Munzel ${ }^{1}$ and C. K. W. Mülling ${ }^{1}$
}

\begin{abstract}
Background: Mechanical interactions between hard floorings and the sole of bovine claws can be reasonable to cause traumatic claw lesions. In this ex vivo study, the direct kinetic impact of concrete and three types of rubber mats on the sole of dairy cattle claws was analyzed. In order to apply uniform loads, isolated distal hind limbs of adult Holstein Friesian dairy cows were functionally trimmed according to the Dutch method and attached to a load applicator. Kinetic data were recorded using a thin, foil-based pressure measurement system (Hoof ${ }^{\mathrm{TM}}$ System, Tekscan ${ }^{\circledast}$.

Results: On concrete, the load distribution between the lateral and medial claw was less balanced than on the rubber floorings. The loaded area was significantly smaller on concrete $\left(32.2 \mathrm{~cm}^{2}\right)$ compared to all rubber mats $\left(48.3-58.0 \mathrm{~cm}^{2}\right)$. Average pressures $\left(P_{\text {av }}\right)$ and maximum pressures $\left(P_{\text {max }}\right)$ were significantly higher on concrete $\left(P_{\text {av }} 44.7 \mathrm{~N} / \mathrm{cm}^{2} ; P_{\max } 130\right.$. $\left.3 \mathrm{~N} / \mathrm{cm}^{2}\right)$ compared to the rubber floorings $\left(P_{a v} 24.9-29.7 \mathrm{~N} / \mathrm{cm}^{2} ; P_{\max } 71.9-87.2 \mathrm{~N} / \mathrm{cm}^{2}\right)$. Pressure peaks occurred mainly in plantar and abaxial parts of the lateral claw and in apical and plantar regions of the medial claw. Load distribution displayed a widely unloaded slope region, but considering the pressure distribution under the claw, none of the zones showed a generally lower pressure exposure.
\end{abstract}

Conclusions: Altogether, rubber floorings lead to a significant mechanical relief of the sole compared to concrete. Furthermore, relevant differences between the tested rubber mats could be determined. Therefore the used system may be applied to compare further flooring types.

Keywords: Bovine claw, Dairy cattle, Pressure distribution, Concrete floor, Rubber mat

\section{Background}

Hard flooring systems such as concrete are the reason for a significantly higher risk of claw diseases and developing lameness in dairy cattle $[1,2]$. Still, some studies proved a higher incidence of sole ulcers on rubber floorings than on concrete [3, 4], albeit with lower severity [5]. In contrast, Benz [6] found out that cows kept on rubber floorings showed a significantly lower incidence of claw diseases which increased again when the animals returned to concrete flooring. Besides, cows kept on rubber showed significantly more comfort behavior than those kept on concrete and walked longer distances, almost comparable to cows on pasture $[7,8]$.

\footnotetext{
* Correspondence: benjamin.oehme@vetmed.uni-leipzig.de ${ }^{1}$ Institute of Veterinary Anatomy, Histology and Embryology, Faculty of Veterinary Medicine, Leipzig University, Leipzig, Germany Full list of author information is available at the end of the article
}

To understand the underlying reasons of the mentioned differences in claw health and cow comfort, the effects of different floorings on the pressure load of bovine claws have been investigated in previous studies [9-11]. As most of the conducted surveys used stationary force or pressure measuring plates with hard surfaces, no direct interactions between flooring type and claw as well as the effects on the individual claw could be captured [12].

Franck et al. [12] applied thin, foil-based pressure sensitive sensors to investigate the direct impact of different concrete surface roughnesses on the pressure distribution under isolated bovine claws. With same type sensors, Nilsson et al. [13] analyzed the pressure distribution under isolated bovine distal limbs on slatted concrete flooring at different positions to the slats. In vivo measurements with large animals using these piezoresistive sensor foils have

(c) The Author(s). 2018 Open Access This article is distributed under the terms of the Creative Commons Attribution 4.0 International License (http://creativecommons.org/licenses/by/4.0/), which permits unrestricted use, distribution, and 
solely been performed in equine kinetic research so far [14-18].

An evaluation of these equine sensors (Tekscan ${ }^{\circ}$ Hoof ${ }^{\text {ix }}$ System) found less accuracy in measuring vertical Ground Reaction Force (vGRF) compared to force plates, but overall results did not differ significantly [19]. Especially after proper calibration the piezoelectric sensors showed a reliable accuracy $[20,21]$. The system was tested and recommended for scientific and clinical application by Lange et al. [17].

The aim of this study was to establish a laboratory setup for kinetic examinations of the bovine distal limb and to directly analyze the kinetic influence of different flooring types to the sole of dairy cattle's claws for the first time.

\section{Methods}

\section{Material}

Twelve left hind limbs of adult Holstein Friesian dairy cows (age $5.0 \pm 1.6$ years) from an abattoir were separated below the tarsometatarsal joint immediately after slaughter and transported to the lab. All claws were trimmed according to the Dutch method [22]. The limbs and claws showed no macroscopically visible pathologies. Metatarsi were cut with a band saw in the proximal third. The medullary cavity of each metatarsus was filled with Demotec ${ }^{\circ} 95$ (Demotec Demel e.K., Nidderau, Germany) in order to fix a threaded bolt in the medullary canal to attach the limb to the load applicator.

Four different floorings were evaluated including concrete (con) and three types of rubber mats (Table 1): KARERA (Kar), KURA (Kur) and profiKURA (proK) (Gummiwerk KRAIBURG GmbH\&Co. KG, Waldkraiburg, Germany).

\section{Pressure measuring system}

A foil-based piezoresistive pressure measurement system (M3200E, Hoof ${ }^{\text {"I }}$ System, Tekscan Inc., Boston, MA, USA) was used. The sensor foils were $0.23 \mathrm{~mm}$ thick with a sensor matrix of $167.6 \times 167.6 \mathrm{~mm}$ and a resolution of 3.9 sensels $/ \mathrm{cm}^{2}$. A $1.5 \mathrm{~mm}$ adhesive protective foil covered the sensors on both sides.

\section{Experimental setup}

The distal limbs were attached to a load applicator and positioned centrally on the sensor with the metatarsus perpendicular to the tested floor. In order to simulate the in vivo situation as closely as possible the deep digital flexor tendon and the digital extensor tendons were pulled proximally with 500 and $50 \mathrm{~N}$ respectively. A securing strap was attached round the pastern joint to stabilize the phalangeal bone axis, which was monitored by latero-medial fluoroscopy. The limbs were loaded vertically with $240 \mathrm{~kg}$ resulting in a final load of $143 \pm 9 \mathrm{~kg}$ under the claws, which was determined by a digital scale (Fig. 1). The lower resultant load was caused by the tendon traction in opposite direction and the horizontal Ground Reaction Forces, which were not captured by the sensors or the scale.

On every flooring a sequence of four repeated measurements was performed. The sensors were initially conditioned with loads up to $300 \mathrm{~kg}$ and subsequently calibrated before and after every sequence with 20 and $80 \%$ of the maximum applied load [23].

\section{Data processing}

In the subsequent data processing, the HoofSCAN Research software (version 6.85, Tekscan Inc., Boston, MA, USA) was used to analyze the force balance (FB), calculated from vertical Ground Reaction Forces (vGRF) of lateral and medial claw $\left(F B=\frac{v G R F_{\text {lat }}}{v G R F_{\text {med }}}\right)$, the total loaded area $\left(\mathbf{A}_{\text {total }}\right)$, average pressure $\left(\mathbf{P}_{\text {av }}\right)$ and maximum pressure $\left(\mathbf{P}_{\text {max }}\right)$ on the four tested floorings under both claws. Afterwards, data were exported to RStudio [24] and by combining the pressure maps with computed tomography-based sole surface areas, a zonal subdivision was implemented according to Carvalho et al. [25] (Fig. 2). By this, the occurrence of $\mathrm{P}_{\max }$ could be localized per claw. Parameters to compare the zones of each claw between the different floorings were the vGRF relative to the total vGRF per side $\left(\mathbf{F}_{\text {side }}\right)$, the loaded area per zone relative to the total zone area $\left(\mathbf{A}_{\text {zone }}\right)$ and the vGRF per loaded area per zone, which describes the pressure in each zone $\left(\mathbf{P}_{\text {zone }}\right)$.

Table 1 Overview and characteristics of tested rubber mats (Gummiwerk KRAIBURG GmbH\&Co. KG)

\begin{tabular}{|c|c|c|c|c|c|c|}
\hline & $\begin{array}{c}\text { thickness } \\
{[\mathrm{mm}]}\end{array}$ & $\begin{array}{c}\text { shore } \\
\text { hardness }\end{array}$ & \multicolumn{2}{|c|}{ surface profile } & \multicolumn{2}{|c|}{ bottom profile } \\
\hline KARERA & 21 & 65 & squares & Ese- & $\begin{array}{c}\text { squares } \\
\text { (height } 2.5 \mathrm{~mm} \text { ) }\end{array}$ & \\
\hline KURA & 24 & 65 & grip profile & & $\begin{array}{c}\text { knobs } \\
\text { (height } 5.0 \mathrm{~mm} \text { ) }\end{array}$ & 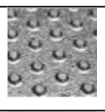 \\
\hline profiKURA & 24 & 65 & $\begin{array}{c}\text { star-shaped } \\
\text { (with Corundum) }\end{array}$ & 802 & $\begin{array}{c}\text { knobs } \\
\text { (height } 5.0 \mathrm{~mm} \text { ) }\end{array}$ & $\begin{array}{r}1 \\
0 y \\
0 y 0 \\
0\end{array}$ \\
\hline
\end{tabular}



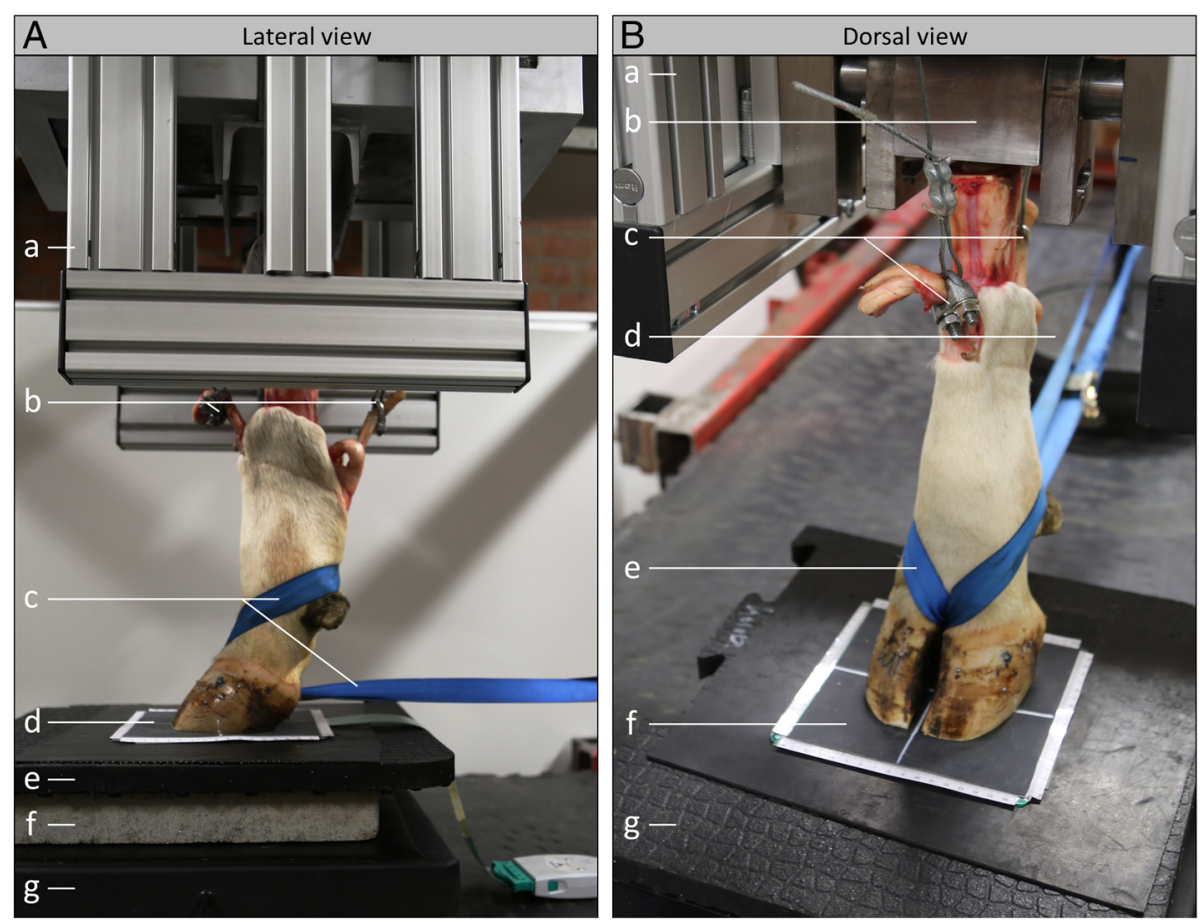

Fig. 1 Experimental setup. A Lateral view: $a=$ load applicator, $b=$ clamped tendons, $c=$ securing strap, $d=$ sensor foil, $e=$ rubber mat, $f=$ concrete, $\mathrm{g}=$ digital scale. $\mathbf{B}$ Dorsal view: $\mathrm{a}=$ load applicator, $\mathrm{b}=\mathrm{cam}, \mathrm{c}=$ clamped tendons, $\mathrm{d}=$ tendon weight, $\mathrm{e}=$ securing strap, $\mathrm{f}=$ sensor foil, $g=$ rubber mat

\section{Statistical analysis}

Statistical analysis was conducted with the software RStudio [24]. Graphical assessment and the Shapiro-Wilk test were applied to determine normal distribution. As numerous data frames were non-parametric, statistical significances were tested using Wilcoxon signed-rank test. Post

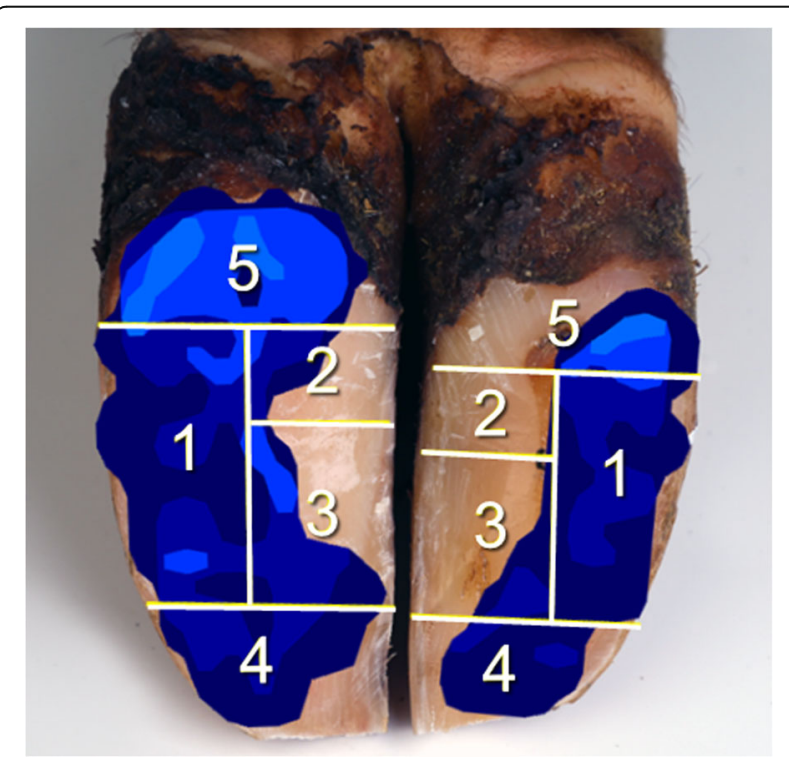

Fig. 2 Subdivision of the sole according to Carvalho et al. [25] hoc correction was carried out with Bonferroni-Holm procedure. First of all, differences of overall parameter data $\left(A_{\text {total }}, P_{a v}, P_{\text {max }}\right)$ were analyzed between the four tested floors. Subsequently, parameters regarding the zones were examined separately for the lateral and medial claw. The parameters $\mathrm{A}_{\text {zone }}$ and $\mathrm{P}_{\text {zone }}$ were compared between the tested floorings for every zone. $F_{\text {side }}$ was analyzed for differences between the floorings and between the five zones. Differences were considered to be significant at $p<0.05$.

\section{Results}

For all tested floorings, the overall load was distributed unevenly between the lateral and medial claw on average. On concrete, the lateral claw was loaded 4.2 times higher than the medial claw. This imbalance decreased significantly on the tested rubber floorings, where the load on the lateral claw was 3.4 (Kar), 2.8 (Kur) and 2.7 (proK) times higher compared to the medial claw.

The total loaded area (Fig. 3a) was significantly smaller on concrete $\left(33.2 \pm 3.4 \mathrm{~cm}^{2}\right)$ than on all tested rubber floorings and differed significantly between all types of rubber mats (Kar $48.3 \pm 3.5 \mathrm{~cm}^{2}$, Kur $52.3 \pm 4.8 \mathrm{~cm}^{2}$, proK $58.0 \pm 3.8 \mathrm{~cm}^{2}$ ) (Fig. 4).

The lowest average pressure (Fig. $3 \mathrm{~b}$ ) was found on profiKURA $\left(24.9 \pm 2.6 \mathrm{~N} / \mathrm{cm}^{2}\right)$. Average pressure differed significantly between all floorings and was highest on 

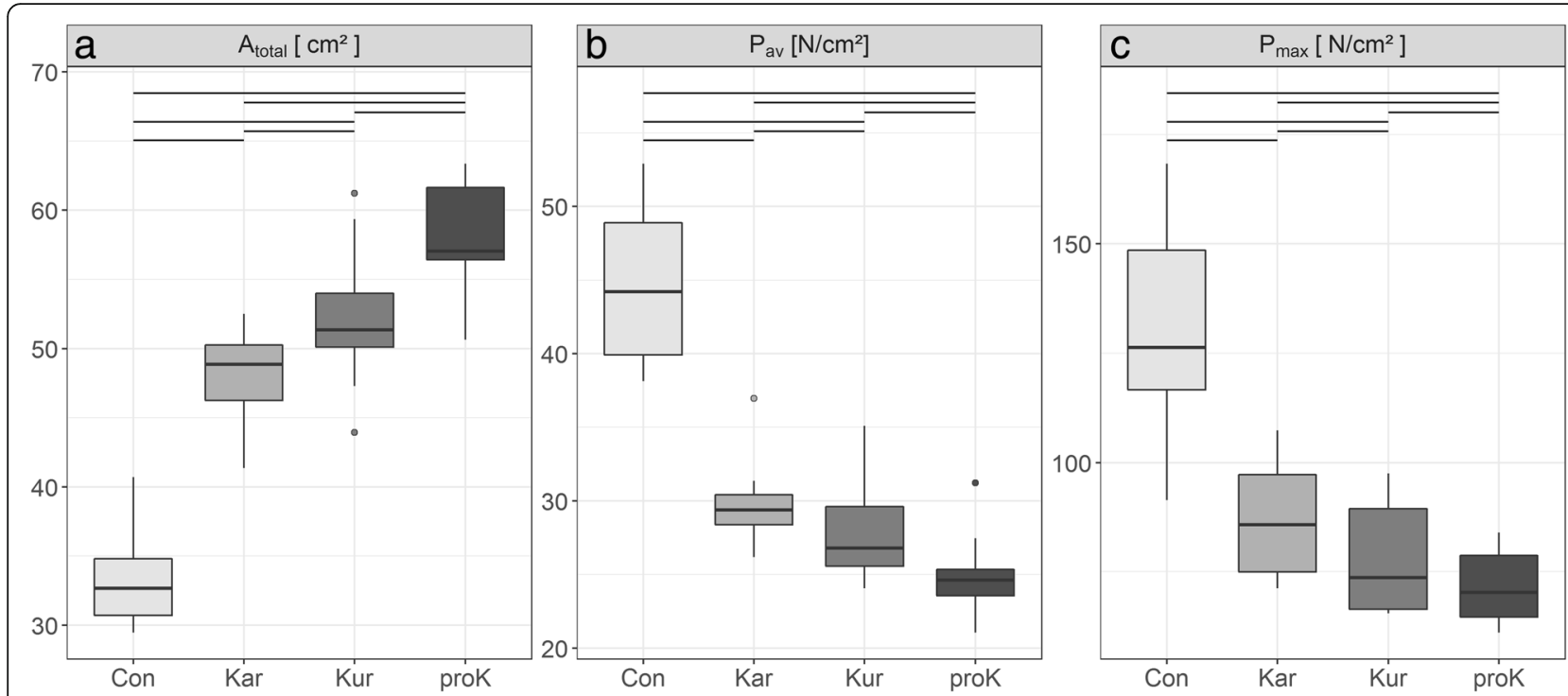

Fig. 3 a Contact area, b average pressure and $\mathbf{c}$ maximum pressure. Boxplots of values on the four tested floorings (concrete (con) and the three rubber mats KARERA (Kar), KURA (Kur) and profiKURA (proK)). Horizontal lines at the top indicate significant differences between the flooring types

concrete (Kur $27.6 \pm 3.3 \mathrm{~N} / \mathrm{cm}^{2}$, Kar $29.7 \pm 2.7 \mathrm{~N} / \mathrm{cm}^{2}$, con $\left.44.7 \pm 5.5 \mathrm{~N} / \mathrm{cm}^{2}\right)$.

Also maximum pressure values (Fig. 3c) were significantly higher on concrete $\left(130.3 \pm 23.7 \mathrm{~N} / \mathrm{cm}^{2}\right)$ compared to all rubber floorings. Significant differences occurred between the three types of rubber flooring as well (Kar $87.2 \pm 13.4 \mathrm{~cm}^{2}$, Kur $78.6 \pm 12.6 \mathrm{~cm}^{2}$, proK $\left.71.9 \pm 8.3 \mathrm{~cm}^{2}\right)$.

Analysis of kinetic characteristics in the different zones showed the following results: The majority of maximum pressure values in the lateral claw were measured in zones 1 and 5 and rarely in zone 4 . Additionally, the occurrence of maximum pressures decreased in zone 1 and increased in zone 5 depending on type of flooring (Fig. 5). Considering the medial claw, the maximum pressures appeared mainly in zones 4 and 5 and to some extent in zone 1. In both claws, isolated pressure peaks occurred in zone 2 and none in zone 3.
There were no significant differences in $\mathrm{F}_{\text {side }}$ between the different floorings. Considering $\mathrm{F}_{\text {side }}$ averaged over all tested floors, zones 1 and 5 bore the highest vertical Ground Reaction Forces (vGRF) in the lateral claw $\left(\mathrm{F}_{\text {side }}\right.$ mean: 40.1 and $32.1 \%)$. In the medial claw the highest amount of load appeared in zones 1,4 and $5\left(\mathrm{~F}_{\text {side }}\right.$ mean: 24.8, 35.2 and 28.3\%). Zones 2 and 3 carried the smallest loads on both sides $\left(\mathrm{F}_{\text {side }}\right.$ between 3.4 and $\left.8.6 \%\right)$ and were significantly different in terms of the vGRF to all other zones. Furthermore, significant differences could be determined between zone 1 and 4 as well as 4 and 5 in the lateral claw (Table 2).

Generally, the relative loaded area per zone $\left(\mathrm{A}_{\text {zone }}\right)$ increased on rubber mats compared to concrete (Fig. 6). Except for zone 2 the loaded area differed significantly between concrete and at least two rubber mats. There were also some significant differences in loaded areas between the tested rubber floorings (Table 3).

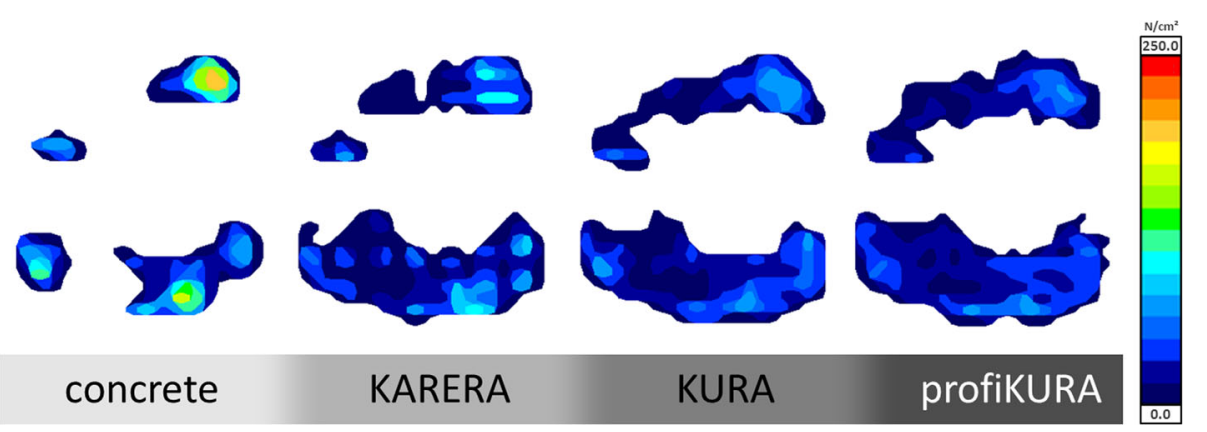

Fig. 4 Exemplary pressure imprints of one claw on the different tested floorings 

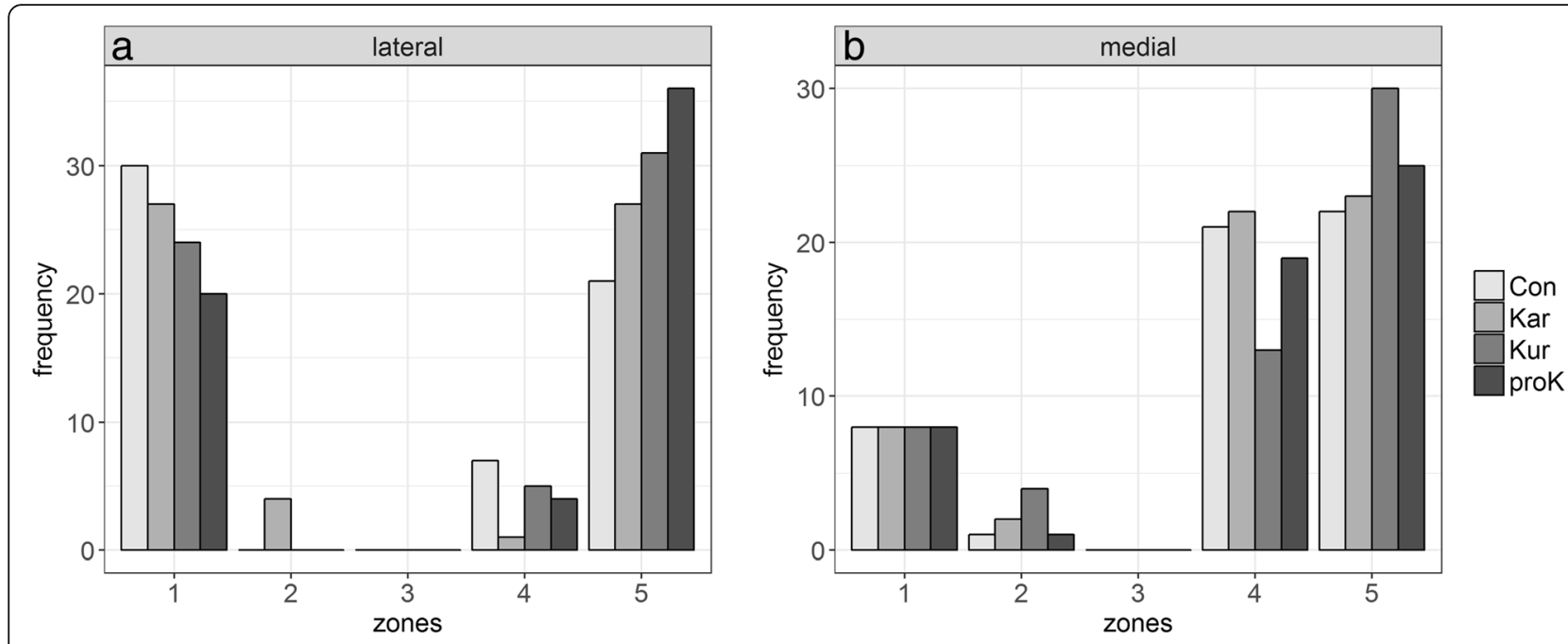

Fig. $\mathbf{5}$ Localization of maximum pressure peaks for the $\mathbf{a}$ lateral and $\mathbf{b}$ medial claw

The pressure in each zone based on the loaded area $\left(\mathrm{P}_{\text {zone }}\right)$ showed significant differences between concrete and rubber floorings for the lateral zones 1 and 4 and for the medial zone 4 (Fig. 7). In the loaded areas of the slope, represented by zones 2 and 3, pressure loads $\left(14.52 \mathrm{~N} / \mathrm{cm}^{2}-37.05 \mathrm{~N} / \mathrm{cm}^{2}\right)$ similar to zones 1,4 and 5 $\left(17.19 \mathrm{~N} / \mathrm{cm}^{2}-50.49 \mathrm{~N} / \mathrm{cm}^{2}\right.$ ) occurred (Table 4$)$.

\section{Discussion}

A physiological positioning and loading of isolated limbs is hard to achieve. The load applicator used in this study was specifically designed for static load application on isolated bovine distal limbs. The applied load of $150 \mathrm{~kg}$ was based on findings of Chapinal et al. [26] and Fischer [27] and was found suitable to mimic the load situation in living animals. As no specific data for cattle are available, tendon loads were adapted to tendon strains in walking ponies [28] and adjusted to a feasible order of magnitude. Previous studies suppressed the influence of most parts of the limbs' anatomical structures by fixating the flexible sections [13] or by solely using the horn capsules $[29,30]$ for standardized kinetic evaluation of flooring impacts on the claws. As these designs neglect physiological dynamic properties, conclusions to in vivo conditions have to be drawn carefully [29]. Therefore, the setup in the present study influenced the movement of joints and tendons as little as possible but still emphasized the normal axis of the distal phalangeal bones, which was monitored with fluoroscopy. Still, after several load applications a dorsiflexion of the pastern joint was observed in preliminary tests. Therefore this joint was stabilized with a securing strap to achieve a consistent, physiological bone axis and force transmission over all repeated measurements (Fig. 1). Despite this, the experimental setup in this study emulates the in vivo situation as closely as possible and enables a standardized examination of effects of different flooring types by exclusion of most interfering and environmental impacts such as body weight, motion, load shifting etc.

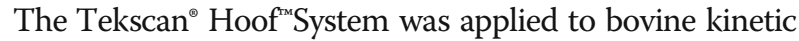
research for the first time in this study. It has frequently been used in equine research and was recommended for scientific and clinical application by Lange et al. [17]. As some authors stated a lack of accuracy in using this piezoresistive foil sensors $[19,21,31]$, most equine studies were confined to relative comparisons [14, 15, 17]. However, by use of an appropriate calibration under trial conditions and expected loads, an adequate accuracy could be obtained with this sensors [19-21]. Therefore, the sensors in this study were calibrated frequently and under measurement

Table 2 Means and standard deviations of $F_{\text {side }}$

\begin{tabular}{llllll}
\hline Zone & 1 & 2 & 3 & 4 & 5 \\
\hline $\begin{array}{l}\text { Lateral claw } \\
\text { all floorings }\end{array}$ & $0.40 \pm 0.12^{2,3,4}$ & $0.08 \pm 0.03^{1,4,5}$ & $0.07 \pm 0.04^{1,4,5}$ & $0.13 \pm 0.05^{1,5}$ & $0.32 \pm 0.10^{2,3,4}$ \\
$\begin{array}{l}\text { Medial claw } \\
\text { all floorings }\end{array}$ & $0.25 \pm 0.16^{2,3}$ & $0.05 \pm 0.04^{1,4,5}$ & $0.06 \pm 0.08^{1,4,5}$ & $0.35 \pm 0.24^{2,3}$ & $0.28 \pm 0.14^{2,3}$ \\
\hline
\end{tabular}

Data averaged over all tested flooring types for the lateral and medial claw and all five zones. Superscript numbers indicate significant differences between the stated zones 


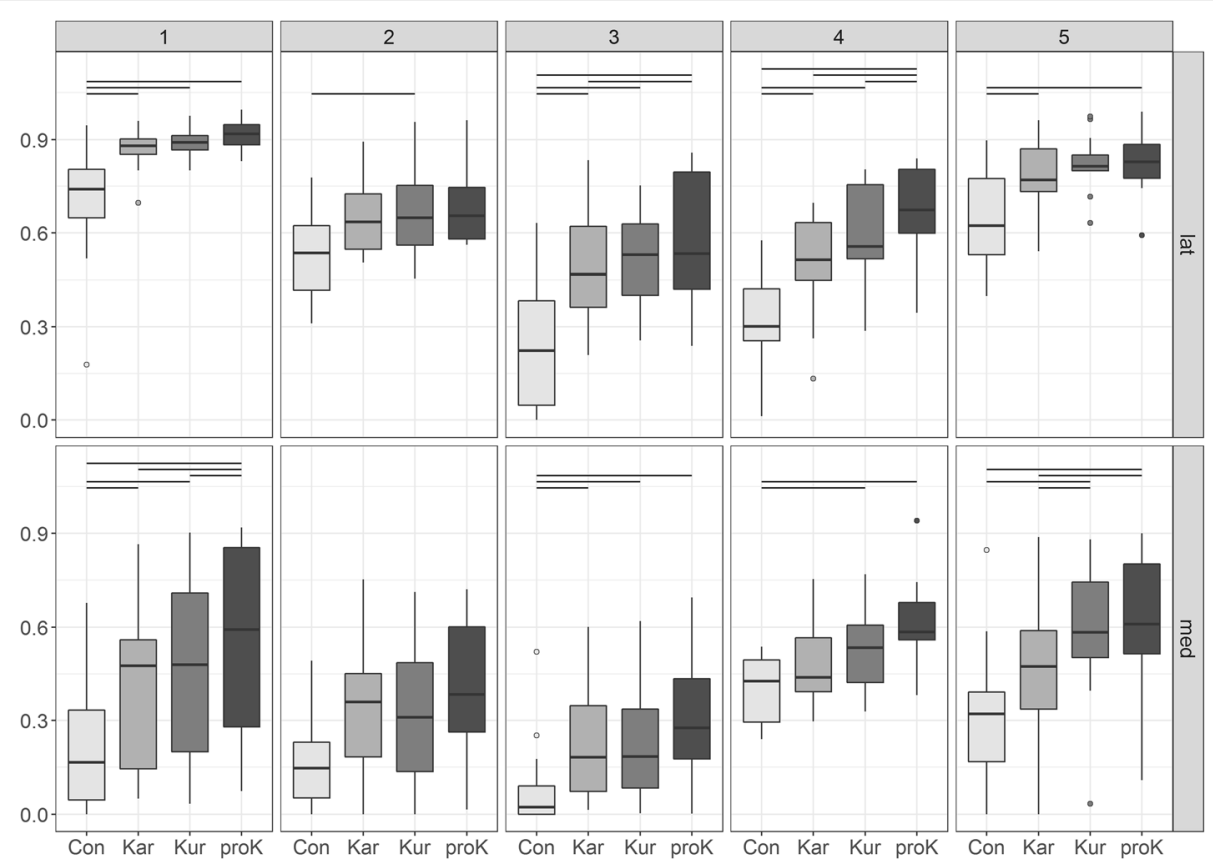

Fig. 6 Loaded area per zone relative to total zone area. Boxplots of $A_{\text {zone }}$ for the lateral and the medial claw, all five zones and the four tested floorings (concrete (con) and the three rubber mats KARERA (Kar), KURA (Kur) and profiKURA (proK)). Horizontal lines at the top indicate significant differences between the flooring types

conditions to minimize the inaccuracy and to guarantee the same conditions for all measurements [23].

The load imbalance between the lateral and medial claw is in accordance with previous in vivo studies [32-34]. However, the lateral claw carried an even higher part of the total load in this study. This may be due to the strict perpendicular position of the limb and the lack of compensatory movement of the proximal structures. Therefore, a larger part of the force is transmitted to the longer lateral digit [35]. The reduction of imbalance on KURA and profiKURA compared to concrete shows a balancing effect of these rubber floorings on load distribution. Furthermore, the loaded area showed significant differences between the three tested rubber floorings. As all rubber mats have the same core structure and shore hardness (Table 1), the larger contact area might originate from the mats' thickness and surface structure. KARERA is thinner compared to the other tested rubber mats and has no knobs underneath, which can explain the smaller contact areas and higher pressure loads compared to KURA and profiKURA. KURA and profiKURA only differ in surface relief and a softer, thin corundum containing top layer on

Table 3 Means and standard deviations of $A_{z o n e}$

\begin{tabular}{|c|c|c|c|c|c|}
\hline Zone & 1 & 2 & 3 & 4 & 5 \\
\hline \multicolumn{6}{|c|}{ Lateral claw } \\
\hline con & $0.69 \pm 0.21$ Kar,Kur,proK & $0.53 \pm 0.15^{\text {Kur }}$ & $0.24 \pm 0.21^{\text {Kar,Kur,proK }}$ & $0.33 \pm 0.16^{\text {Kar,Kur,prok }}$ & $0.65 \pm 0.17$ Kar,proK \\
\hline Kar & $0.87 \pm 0.07$ con & $0.13 \pm 0.60$ & $0.49 \pm 0.20$ con,prok & $0.50 \pm 0.17^{\text {con,prok }}$ & $0.78 \pm 0.12^{\text {con }}$ \\
\hline Kur & $0.89 \pm 0.05^{\text {con }}$ & $0.16 \pm 0.05^{\text {con }}$ & $0.52 \pm 0.16^{\text {con }}$ & $0.58 \pm 0.17^{\text {con,prok }}$ & $0.82 \pm 0.09$ \\
\hline prok & $0.91 \pm 0.05^{\text {con }}$ & $0.13 \pm 0.06$ & $0.58 \pm 0.20^{\text {con,Kar }}$ & $0.66 \pm 0.17$ con,Kar,Kur & $0.83 \pm 0.11$ con \\
\hline \multicolumn{6}{|c|}{ Medial claw } \\
\hline con & $0.21 \pm 0.20$ Kar,Kur,proK & $0.16 \pm 0.14$ & $0.09 \pm 0.16^{\text {Kar,Kur,prok }}$ & $0.40 \pm 0.11$ Kur,prok & $0.31 \pm 0.25$ Kur,prok \\
\hline Kar & $0.42 \pm 0.26^{\text {con,prok }}$ & $0.33 \pm 0.22$ & $0.22 \pm 0.18$ con & $0.49 \pm 0.15$ & $0.48 \pm 0.25$ Kur,prok \\
\hline Kur & $0.48 \pm 0.29$ con,prok & $0.33 \pm 0.22$ & $0.24 \pm 0.22^{\mathrm{con}}$ & $0.54 \pm 0.15^{\mathrm{con}}$ & $0.58 \pm 0.23$ con,Kar \\
\hline prok & $0.57 \pm 0.30^{\mathrm{con}, \mathrm{Kar}, \mathrm{Kur}}$ & $0.40 \pm 0.23$ & $0.32 \pm 0.23^{c o n}$ & $0.61 \pm 0.15^{\mathrm{con}}$ & $0.63 \pm 0.22^{\text {con, Kar }}$ \\
\hline
\end{tabular}

Relative values for the lateral and the medial claw, all five zones and the four tested floorings (concrete (con) and the three rubber mats KARERA (Kar), KURA (Kur) and profiKURA (proK)). Superscript abbreviations indicate significant differences between these floorings 


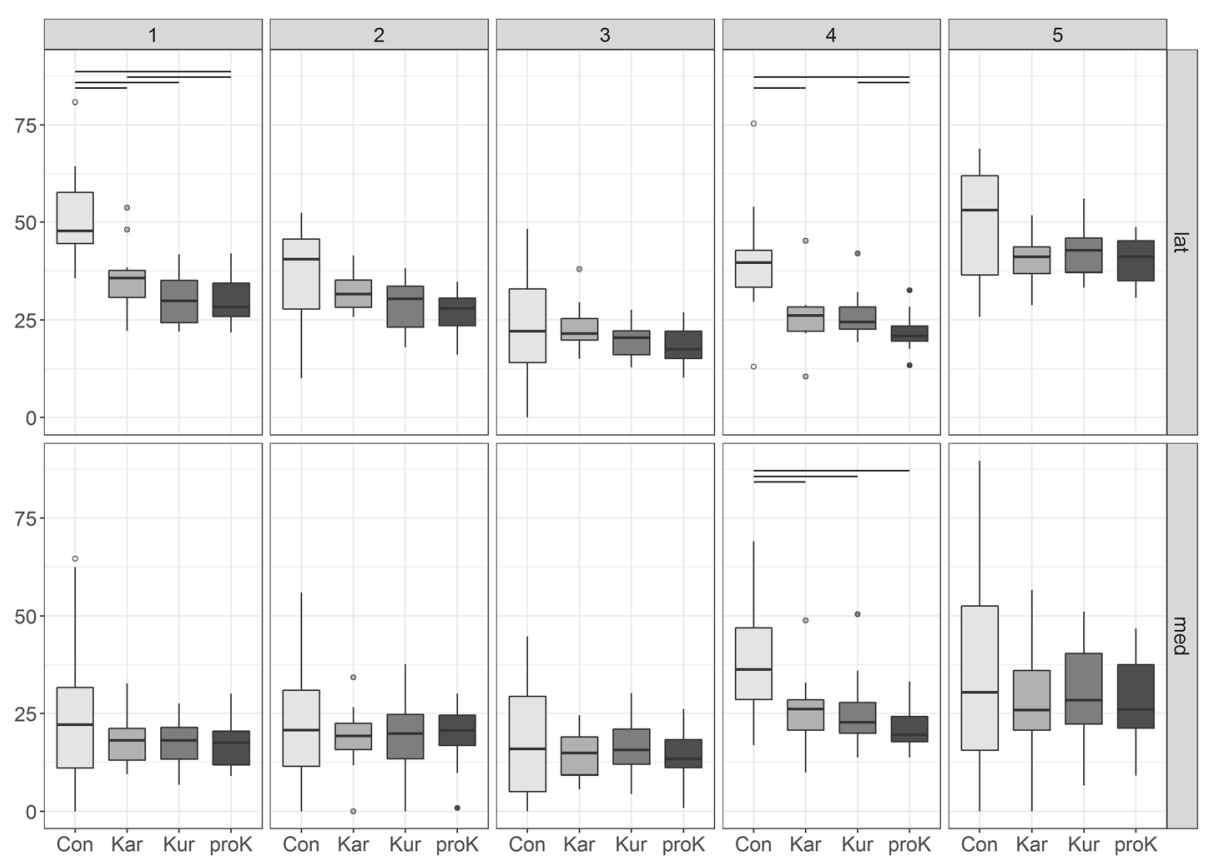

Fig. 7 Pressure in each zone, referred to the loaded area. Boxplots of $P_{z o n e}\left[N / \mathrm{cm}^{2}\right]$ for the lateral and the medial claw, all five zones and the four tested floorings (concrete (con) and the three rubber mats KARERA (Kar), KURA (Kur) and profiKURA (proK)). Horizontal lines at the top indicate significant differences between the flooring types

profiKURA. These differences in surface texture may provide smoother contact to the sole and obviously lead to a more regular load distribution.

The higher average and maximum pressures on concrete compared to the rubber floorings result from the smaller loaded area combined with a uniformly applied load. Especially the high pressure peaks on concrete flooring are capable of damaging the claw horn tissue, in particular in the soft bulb, which has a lower compressive strength than the wall horn [36]. As visible in Fig. 3c, these pressure peaks can be reduced considerably on the tested rubber floorings.
Additionally, the variance of pressure peaks is much higher on concrete than on the rubber floorings, which is consistent with findings of Luo et al. [37]. The high influence of the claws itself on the pressure distribution [29] may explain the generally high deviations found in the present study. Therefore it is advisable to compare the effect of different floorings and treatments rather within each claw than between entire groups of limbs.

By comparing the results of this kinetic analysis with the in vivo findings of van der Tol et al. [33] and Fischer [27], the contact area in the current study is substantially smaller. This may originate from the concrete's irregular

Table 4 Means and standard deviations of $\mathrm{P}_{\text {zone }}\left[\mathrm{N} / \mathrm{cm}^{2}\right]$

\begin{tabular}{|c|c|c|c|c|c|}
\hline Zone & 1 & 2 & 3 & 4 & 5 \\
\hline \multicolumn{6}{|c|}{ Lateral claw } \\
\hline con & $51.25 \pm 12.36^{\text {Kar,Kur,prok }}$ & $36.51 \pm 12.34$ & $22.89 \pm 14.53$ & $40.20 \pm 14.17^{\text {Kar,proK }}$ & $50.11 \pm 13.75$ \\
\hline Kar & $35.85 \pm 8.24$ con, prok & $32.33 \pm 4.64$ & $23.28 \pm 5.99$ & $26.02 \pm 7.57$ con & $40.69 \pm 6.19$ \\
\hline Kur & $30.40 \pm 6.05^{\text {con }}$ & $28.87 \pm 6.49$ & $19.98 \pm 4.54$ & $26.37 \pm 5.95^{\mathrm{prok}}$ & $42.81 \pm 7.28$ \\
\hline prok & $29.76 \pm 5.78^{\mathrm{con}, \mathrm{Kar}}$ & $26.34 \pm 5.44$ & $18.54 \pm 4.82$ & $22.07 \pm 4.91$ con,Kur & $40.35 \pm 5.54$ \\
\hline \multicolumn{6}{|c|}{ Medial claw } \\
\hline con & $25.22 \pm 20.51$ & $21.57 \pm 15.50$ & $18.17 \pm 15.04$ & $38.05 \pm 14.81$ Kar,Kur,prok & $37.06 \pm 29.35$ \\
\hline Kar & $18.55 \pm 6.53$ & $18.78 \pm 8.10$ & $14.63 \pm 5.59$ & $25.76 \pm 9.04$ con & $27.99 \pm 13.88$ \\
\hline Kur & $18.01 \pm 5.95$ & $19.34 \pm 9.79$ & $16.38 \pm 7.16$ & $25.45 \pm 9.44$ con & $29.93 \pm 12.40$ \\
\hline prok & $17.24 \pm 5.93$ & $19.35 \pm 7.85$ & $13.92 \pm 6.34$ & $21.56 \pm 6.31$ con & $27.72 \pm 10.96$ \\
\hline
\end{tabular}

Pressure values for the lateral and the medial claw, all five zones and the four tested floorings (concrete (con) and the three rubber mats KARERA (Kar), KURA (Kur) and profiKURA (proK)). Superscript abbreviations indicate significant differences between these floorings 
surface compared to the smooth metal surfaces of the pressure plates used in the former surveys. The same applies to the higher maximum pressure values occurring in the present study compared to the analyzed pressure peaks of van der Tol et al. [33]. However, the average pressure was concordant with results of Telezhenko et al. [11] and van der Tol et al. [33]. Thus, the magnitude of the pressure loads determined in this study can be transferred to in vivo conditions and the effect of flooring types on the load under live cattle's claws can be estimated.

While maximum pressures occur particularly in the plantar and abaxial zones of the lateral claw, the medial claw bears maximum pressures both in the apical and plantar zones and fewer pressure peaks were found in the abaxial zone. This is largely in accordance with the findings of Carvalho et al. [25]. Although van der Tol et al. [38] used a zonal subdivision different from the present study, parallels in localization of maximum pressure peaks can be established. Still a few pressure peaks, mainly on rubber floorings, occurred in the plantar sectors of the slope, which represents the region prone to sole ulcer. This may explain the higher prevalence of sole ulcers in dairy cattle on rubber floorings found by some authors $[3,4]$. This, in turn, may lead to the conclusion that the Dutch method [22], which was challenged by other authors before [25, 33], may not be appropriate for dairy cows housed on rubber flooring systems.

The relative distribution of $\mathrm{vGRF}$ on the different zones $\left(\mathrm{F}_{\text {zone }}\right)$ showed that zones 2 and 3 carried only a little proportion of the exerted load. That implies that these zones representing the slope were less burdened compared to the other zones. However, analysis of average pressure showed no general relief of these two zones. Consequently, the impacting forces might be lower but limited to a smaller area in the zones 2 and 3, which results in a pressure extent similar to the other zones.

Although an increase of loaded area between concrete and the tested rubber floorings was observed in all zones except zone 2, no associated overall decrease of mean pressure could be determined. The lack of significant differences in pressure loads between the floorings may originate from the widely varying loading patterns between the examined distal limbs. That may also be caused by the missing compensating movement of proximal structures in the used load applicator. Further, the influence of the claws itself may be a reason for the varying load distribution patterns, which has been stated by Franck et al. [12] before. Therefore, general inferences on pressure distribution over the different regions of the claws' contact area have to be drawn carefully and may require a greater number of tested limbs.
Nevertheless, the effects of the tested rubber floorings on the overall kinetic patterns of the claw $\left(\mathrm{FB}, \mathrm{A}_{\text {total }}, \mathrm{P}_{\mathrm{av}}\right.$, $\left.\mathrm{P}_{\max }\right)$ showed a clear reduction of mechanical stress to the claws' sole in comparison to concrete. Comparable effects were recently found by Hüppler et al. [15] between concrete and soft floorings in standing and walking horses. In the present study, even differences between the tested rubber floorings in loaded area and overall pressure load could be observed. It seems, that profiKURA induces the least mechanical stress, followed by KURA and KARERA.

This investigation serves as a basis for analyzing direct kinetic influences of different flooring properties on the bovine claw in live animals. To confirm the results obtained in this study, further analysis with more specimens might be needed. Furthermore, the measuring system and the ex vivo findings have to be validated in live cows, as compensating movements of proximal structures or the location of the body's center of gravity cannot be simulated with this setting. Nevertheless, the ex vivo setup is beneficial regarding restrictions in terms of welfare reason and financial considerations and can be used to assess effects of further floorings or claw trimming methods without applying them to live animals initially.

\section{Conclusion}

In this study it was possible to detect lower pressure loads on rubber floorings compared to concrete. Furthermore, even differences between varying rubber floorings could be determined. This reduction of mechanical stress, in particular maximum pressure peaks, is one component to reduce the risk of mechanically induced claw diseases.

\section{Acknowledgements \\ The authors acknowledge Enrico Reich, Nicole Röhrmann and Monique Weiß (Faculty of Veterinary Medicine of Leipzig University, Germany) for assisting with the data collection and processing. \\ Funding \\ The project was supported by funds of the Landwirtschaftliche Rentenbank (Frankfurt am Main, Germany). BO receives a scholarship from the Klaus Murmann Fellowship Program of the Foundation of German Business (SDW). Funders had neither influence on the study design and data collection, analysis and interpretation, nor in writing the manuscript. The authors also acknowledge support from the German Research Foundation (DFG) and Leipzig University within the program of Open Access Publishing.}

\section{Availability of data and materials}

The datasets used and analyzed during the current study are available from the corresponding author on reasonable request.

\section{Authors' contributions}

BO made substantial contributions to conception and design, acquisition of data, analysis and interpretation of data and drafted the manuscript. SGe made substantial contributions to conception and design, acquisition of data and revising the manuscript critically for important intellectual content. SGr made substantial contributions to conception and design, acquisition of data, was involved in drafting and revising the manuscript critically for 
important intellectual content. $\mathrm{KH}$ made substantial contributions to data processing, statistical analysis and graph preparation. JM made substantia contributions to conception and design, acquisition of data and revising the manuscript critically for important intellectual content. CM made substantial contributions to conception and design and revising the manuscript critically for important intellectual content. All authors read, revised and approved the final manuscript.

\section{Ethics approval and consent to participate}

Not applicable, because material was purchased from an abattoir

\section{Consent for publication}

Not applicable

\section{Competing interests}

The authors declare that they have no competing interests.

\section{Publisher's Note}

Springer Nature remains neutral with regard to jurisdictional claims in published maps and institutional affiliations.

\section{Author details}

${ }^{1}$ Institute of Veterinary Anatomy, Histology and Embryology, Faculty of Veterinary Medicine, Leipzig University, Leipzig, Germany. ${ }^{2}$ Institute of Topographic Anatomy, University of Veterinary Medicine Vienna, Vienna, Austria.

\section{Received: 27 March 2018 Accepted: 17 August 2018}

\section{Published online: 31 August 2018}

\section{References}

1. Vanegas J, Overton M, Berry SL, Sischo WM. Effect of rubber flooring on claw health in lactating dairy cows housed in free-stall barns. J Dairy Sci. 2006;89(11):4251-8.

2. Vokey FJ, Guard CL, Erb HN, Galton DM. Effects of alley and stall surfaces on indices of claw and leg health in dairy cattle housed in a free-stall barn. J Dairy Sci. 2001:84(12):2686-99.

3. Kremer PV, Nueske S, Scholz AM, Foerster M. Comparison of claw health and milk yield in dairy cows on elastic or concrete flooring. J Dairy Sci. 2007:90(10):4603-11.

4. Fjeldaas T, Sogstad AM, Osterås O. Locomotion and claw disorders in Norwegian dairy cows housed in freestalls with slatted concrete, solid concrete, or solid rubber flooring in the alleys. J Dairy Sci. 2011;94(3): 1243-55

5. Reubold $\mathrm{H}$. Entwicklung geeigneter Parameter zur Beurteilung von elastischen Laufgangauflagen in Liegeboxenlaufställen für Milchkühe [Dissertation med. vet]. Gießen: Justus-Liebig-Universität; 2008.

6. Benz B. Elastische Beläge für Betonspaltenböden in Liegeboxenlaufställen [Dissertation]. Hohenheim: Universität Hohenheim; 2002.

7. Platz S, Ahrens F, Bendel J, Meyer HHD, Erhard MH. What happens with cow behavior when replacing concrete slatted floor by rubber coating: a case study. J Dairy Sci. 2008;91(3):999-1004.

8. Bendel J. Auswirkungen von elastischen Bodenbelägen auf das Verhalten von Milchrindern im Laufstall [Dissertation med. vet]. München: LudwigMaximilians-Universität; 2005.

9. Bergsten C, Telezhenko E, Ventorp M. Influence of soft or hard floors before and after first calving on dairy heifer locomotion, claw and leg health. Animals (Basel). 2015;5(3):662-86.

10. Ouweltjes W, Holzhauer M, van der Tol PPJ, van der Werf JTN. Effects of two trimming methods of dairy cattle on concrete or rubber-covered slatted floors. J Dairy Sci. 2009;92(3):960-71.

11. Telezhenko E, Bergsten C, Magnusson M, Ventorp M, Nilsson C. Effect of different flooring systems on weight and pressure distribution on claws of dairy cows. J Dairy Sci. 2008;91(5):1874-84.

12. Franck $A$, Cocquyt $G$, Simoens $P$, De Belie N. Biomechanical properties of bovine claw horn. Biosyst Eng. 2006;93(4):459-67.

13. Nilsson C, Pålsson K-H, Ventorp M. Pressure distribution on bovine claws in slatted concrete floors. In: Proceedings of XVI CIGR world congress. Düsseldorf: VDI-Verlag; 2006.

14. Hagen J, Hüppler M, Häfner FS, Geiger SM, Mäder D. Modifying horseshoes in the mediolateral plane: effects of side wedge, wide branch, and unilateral roller shoes on the phalangeal alignment, pressure forces, and the footing pattern. J Equine Vet Sci. 2016;37:77-85.

15. Hüppler M, Hagen J, Häfner FS, Geiger SM, Mäder D. Untersuchung der auf den Huf einwirkenden Druckkräfte und deren Beeinflussung durch verschiedene Bodenbeschaffenheiten. Pferdeheilkunde. 2015;31(5):426-34.

16. Al Naem M. Untersuchungen zur Hufrehe bei Pferden mit Hilfe des HufScan ${ }^{\oplus}$-Systems [Dissertation med. vet]. Gießen: Justus-LiebigUniversität; 2014

17. Lange C, Kattelans A, Rohn K, Lüpke M, Brückner HP. Die kinetische Untersuchung der Fußung, der Belastung des Hufes und des Abrollvorganges an den Vordergliedmaßen von Pferden im Schritt und im Trab auf dem Laufband mit dem HoofTM-System (Tekscan ${ }^{\oplus}$ ). Pferdeheilkunde. 2012;28(5):538-47.

18. Reilly PT. In-shoe force measurements and hoof balance. J Equine Vet Sci. 2010;30(9):475-8

19. Perino W, Kawcak CE, Frisbie DD, Reiser RF, Mcllwraith CW. The accuracy and precision of an equine in-shoe pressure measurement system as a tool for gait analysis. J Equine Vet Sci. 2007;27(4):161-6.

20. Hsiao H, Guan J, Weatherly M. Accuracy and precision of two in-shoe pressure measurement systems. Ergonomics. 2002;45(8):537-55.

21. Morin EL, Bryant JT, Reid SA, Whiteside RA. Calibration Issues of Tekscan Systems For Human Pressure Assessment. In: Soldier Mobility: Innovations in Load Carriage System Design and Evaluation. Neuilly-sur-Seine: NATO; 2001. p. 24-1--7.

22. Toussaint RE. Cattle footcare and claw trimming. Ipswich, Suffolk: Farming Press: 1985.

23. Brimacombe JM, Wilson DR, Hodgson AJ, Ho KCT, Anglin C. Effect of calibration method on Tekscan sensor accuracy. J Biomech Eng. 2009;131(3):34503. -1-4

24. RStudio. Integrated Development Environment for R. Boston: RStudio, Inc; 2016

25. Carvalho V, Nääs IA, Bucklin RA, Shearer JK, Shearer L, Massafera VJR, et al. Effects of trimming on dairy cattle hoof weight bearing surfaces and pressure distributions. Braz J Vet Res Anim Sci. 2006;43(4):518-25.

26. Chapinal N, de Passilé AM, Rushen J. Weight distribution and gait in dairy cattle are affected by milking and late pregnancy. J Dairy Sci. 2009;92(2):581-8.

27. Fischer L. Analyse der Druckverteilung unter den Klauen bei Kühen der Rasse Deutsche Holsteins [Dissertation med. vet]. Hannover: Tierärztliche Hochschule Hannover; 2006

28. Riemersma DJ, van den Bogert AJ, Schamhardt HC, Hartman W. Kinetics and kinematics of the equine hind limb: in vivo tendon strain and joint kinematics. Am J Vet Res. 1988;49(8):1344-52.

29. Franck A, De Belie N. Concrete floor-bovine claw contact pressures related to floor roughness and deformation of the claw. J Dairy Sci. 2006;89(8): 2952-64.

30. De Belie N, Rombaut E. Characterisation of claw-floor contact pressures for standing cattle and the dependency on concrete roughness. Biosyst Eng. 2003:85(3):339-46.

31. Sumiya T, Suzuki Y, Kasahara T, Ogata H. Sensing stability and dynamic response of the F-Scan in-shoe sensing system: a technical note. J Rehabil Res Dev. 1998;35(2):192.

32. Kehler W, Gerwing TH. Effects of functional claw trimming on pressure distribution under hind claws of German Holstein cows. In: Zemljic, B, editor. Proceedings of the 13th International Symposium and 5th Conference on Lameness in Ruminants. Maribor, Slovenija; 2004.

33. van der Tol PPJ, van der Beek SS, Metz J, Noordhuizen-Stassen EN, Back W, Braam CR, et al. The effect of preventive trimming on weight bearing and force balance on the claws of dairy cattle. J Dairy Sci. 2004;87(6):1732-8.

34. Gerwing TH. Beeinflussung der Lastverteilung durch Klauenpflege innerhalb der Einzelklauen und der Klauenpaare der Hintergliedmaßen von schwarzbunten Milchkühen der Rasse Deutsche Holsteins [Dissertation med. vet]. Hannover: Tierärztliche Hochschule Hannover; 2003.

35. Muggli E, Sauter-Louis C, Braun U, Nuss K. Length asymmetry of the bovine digits. Vet J. 2011;188(3):295-300.

36. van der Tol PPJ, Metz JHM, Noordhuizen-Stassen EN, Back W, Braam CR, Weijs WA. The vertical ground reaction force and the pressure distribution on the claws of dairy cows while walking on a flat substrate. J Dairy Sci. 2003;86(9):2875-83.

37. Luo ZP, Berglund LJ, An KN. Validation of F-scan pressure sensor system: a technical note. J Rehabil Res Dev. 1998;35(2):186-91.

38. van der Tol PPJ, Metz JHM, Noordhuizen-Stassen EN, Back W, Braam CR, Weijs WA. The pressure distribution under the bovine claw during square standing on a flat substrate. J Dairy Sci. 2002;85(6):1476-81. 